\title{
INTERNAL CAPABILITY BASED ON AHP AND EXTERNAL LINKAGES IN THE INNOVATION OF IN ASEAN FIRMS
}

\author{
Masaru Ogawa \\ Faculty of Business Administration, Kobe Gakuin University, Kobe, Japan \\ Yasusi Ueki \\ Economic Research Institution for ASEAN, Jakarta, Indonesia \\ Hiroki Idota \\ Faculty of Economics, Kinki University, Higashiosaka, Japan \\ Masatsugu Tsuji* \\ Graduate School of Applied Informatics, University of Hyogo, Kobe, Japan \\ e-mail: tsuji@ai.u-hyogo.ac.jp
}

\begin{abstract}
Based on survey data from four ASEAN economies, this paper identifies the content of internal capability at the technological level, in managerial organization, and through human resources. To make this concept more tractable for analysis, the index of internal capability using AHP (Analytical Hierarchy Process) was used. This paper also examines using regroups estimation methods how external sources such as MNCs, universities, and public organizations enhance internal capability. This paper also attempts to identify the transmission mechanisms through which external sources influence internal capability.
\end{abstract}

Keywords: internal capability, external linkages, AHP.

\section{Introduction}

Economic development in East Asia has continued and further agglomeration has been transforming the area from a simple production base to a knowledge-based economy. In order to achieve this, the further empowerment of regional firms to enhance innovation is required. This paper attempts to identify the factors behind innovation in individual firms. Such power is referred to as internal innovation capability, or internal capability, for short. Typical factors are technology, managerial organization, and human capital. More importantly, the issue is how to promote these factors so as to be ready for innovation. There are two domestic measures that individual firms can take to promote these factors: investment in technology and in human resources. Another approach is to make use of factors outside a firm and utilize them to promote internal capability. This paper attempts to identify agents, including MNCs (Multinational Corporations), universities, regional research institutions, and business organizations, which can transfer technology to local firms.

\section{Literature Review}


This paper attempts to identify the factors behind innovation in individual firms. Such power is referred to as innovation capability which is defined as the ability to continuously transform knowledge and ideas into new products, processes and systems for the benefit of the firm and its stakeholders by Lawson \& Samson (2001), for example. Innovation capability consists of various factors, and Mariano \& Pilar (2005) categorizes them into groups such as (1) communication with the external environment; (2) level of know-how and experience within the organization; (3) diversity in the knowledge structure; and (4) strategic positioning. Thus, internal capability, which is defined as an integrated ability of a firm to create innovation which consists of all resources, core competence, or competitiveness. This concept is defined as a firm's ability to reorganize the value of new external knowledge, assimilate to commercial ends (Zahra \& George, 1991). Thus absorptive capability determines the competitive advantage of a firm (Barney, 1991). The internal capability is thus constructed by the factors mentioned above, and the traditional method to obtain the internal capability is factor analysis which categorizes variables into the factors which consist of an internal capability variable. The problem of this is to contain some irrelevant variables, implying that the index is not reflected by true variables. On the other hand, the index constructed by AHP does contain only variables which affect the index. This paper is the first attempt to employ the internal capability constructed in this way in estimation.

\section{Hypotheses/Objectives}

This paper attempts to examine these relationships using econometric analysis. The hypotheses can be summarized as follows:

Hypothesis 1: Internal innovation capability affects (product) innovation.

Hypothesis 2: External sources have no direct effect on innovations, or if they do, their effects are relatively low.

Hypothesis 3: External sources enhance internal innovation capability.

In addition to the above hypotheses, this paper specifies the transmission channel that is a particular route from external sources to a firm's particular internal capability. As explained earlier, an example is dispatching engineers from an external partner, such as an $\mathrm{MNC}$, to a local firm to promote its internal capability. This hypothesis is summarized as follows.

Hypothesis 4: Internal innovation capability is enhanced through a transmission channel from external sources.

\section{Research Design/Methodology}

\subsection{Definition of Internal Innovation Capability}

In this paper, we attempt to identify the internal capability of firms to create innovation according to questions in the questionnaire. We postulate the following three factors which contribute to innovation: (i) technology, (ii) managerial organization, and (iii) human resources. (i) The technological factor is clearly the basis of innovation. These three constitute the "first layer" and are referred to as first layer factors. Moreover, each of these factors consists of its own detailed sub-factors, which form the "second layer." These sub-factors are called the second layer factors. Let us take the example of (i) the technological factor, which includes the following two second layer factors: (a) ratio of $\mathrm{R} \& \mathrm{D}$ expenditure to sales at present asked as Q19.1, and (b) high technical ability (Q8). 
(ii) Managerial organization indicates whether the managerial organization is designed and functioning to encourage exchange and share information among employees. This first layer factor consists of the following three second layer factors: (c) adopted ISO9000/14000 (Q17.1-2), (d) cross-functional team (Q21), and (e) practicing QC circle (Q22.1). Finally, the first layer factor of human resources is an important factor for engaging in innovation activities as well as for design and managing $R \& D$, which consist of the following three second layer factors: (f) career of top management (Q35.3-4,8), (g) career of factory manager $(\mathrm{Q} 36,39)$, and $(\mathrm{h})$ Training/HRD program $(\mathrm{Q} 41,42)$. Figure 1 and Table 1 show the tree structure of the index and related questions in the questionnaire.

Table 1 Weights of factors by AHP

First layer

\begin{tabular}{|l|l|l|c|}
\hline \multirow{2}{*}{ Technical factor } & \multirow{2}{*}{0.490} & R\&D investment & 0.240 \\
\cline { 3 - 4 } & & High technical ability & 0.760 \\
\hline \multirow{3}{*}{ Managerial organization } & \multirow{2}{*}{0.164} & Adopted ISO9000/14000 & 0.104 \\
\cline { 3 - 4 } & & Cross-function team & 0.623 \\
\cline { 3 - 4 } & & Practicing QC & 0.273 \\
\hline \multirow{2}{*}{ Human resources } & \multirow{2}{*}{0.346} & Career of CEO & 0.675 \\
\cline { 3 - 4 } & & Career of factory manager & 0.153 \\
\cline { 3 - 4 } & & Training/HRD program & 0.172 \\
\hline
\end{tabular}

Source: Authors.

\subsection{Distribution of Capability Index}

Based on the weights of factors by AHP, the distribution of the internal innovation capability index of the five regions of Indonesia, Thailand, the Philippines, the Ho Chi Minh City area, and the Hanoi area are shown in Figure 1. The average value of the index of the five areas is 0.388 and the averages of Indonesia, Thailand, the Philippines, the Ho Chi Minh City area, and the Hanoi area are 0.398, 0.400, 0.338, 0.441, and 0.382, respectively.

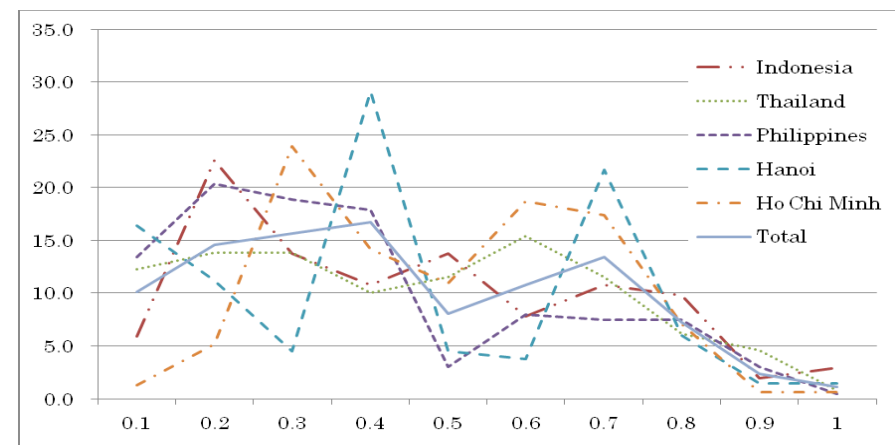

Figure 1 Distribution of internal capability index by countries.

\section{Data/Model Analysis}

\subsection{Estimation Equations}

International Symposium of

Washington, D. C. June 29 - July 2, 2014 
Questionnaires were distributed across regions in Vietnam, the Philippines, Indonesia and Thailand. Each country reported the valid responses and which were as follows: Ha Noi (134), Ho Chi Minh (155) and thus Vietnam (189); the Philippines (201); Indonesia (102); and Thailand (130). Therefore 722 valid responses were reported.

This study analyzes only product innovation, which consists of four types such as "Redesigning packaging or changing appearance design (Type I)," "Significantly improving existing products (Type II)," "New product based on existing technologies (Type III)," and "New product based on new technologies (Type IV)." Models for estimation on innovations and capability are expressed in equation (1) and (2),

$$
\begin{aligned}
& \text { Innovation }_{i}=\alpha_{0}+\alpha_{1} \text { Capability }_{i}+\alpha_{2} \text { External }_{i}+\alpha_{3} X_{i}+u_{i} \\
& \text { Capalirity }_{i}=\beta_{0}+\beta_{1} \text { External }_{i}+\alpha_{2} X_{i}+\alpha_{3} Z_{i}+v_{i}
\end{aligned}
$$

where Innovation ${ }_{i}$ denotes whether the $i$-th firm achieves product innovation. Capability implies its capability index, and External ${ }_{i}$ indicates the external sources, which include following 13 sources which are indicated in Note 2 of Table 2.

\subsection{Estimations Result}

Equation (1) is estimated for four types of product innovation, and here only the result of Type I is described in Table 2. We estimated one equation for one external linkage, and as a result there are 13 cases for equation (1). In Table 2, the estimated coefficients of internal capability index are denoted in the first row, and Table 2 shows all of them are positively significant $(\mathrm{p}<0.01)$. On the other hand, the estimated coefficients of external linkages are shown in the second row, which are not significant at all. These imply that internal capability affects the probability of achieving product innovation, while external linkages do not. The similar results are obtained for other types of product innovation. Let examine the result of equation (2); whether external linkages affect internal capability index. Again in Table 2, the estimated coefficients of external linkages are denoted in the third row, and the results demonstrate that all 13 external sources have effects on internal capability basically, except for case 5 "Local customer in country" only in the case of product innovation I. This external source does not have positively significant to internal capability index. The similar results are obtained for other types of product innovation.

\section{Limitations}

In this paper, the endogeneity problem is taken care of in the innovation model as shown in Table 2. It seems that all the policy recommendations proposed are thus rather comprehensive and generally applicable. Since resources to promote innovation and strategic policy measures which target specific objectives are limited, in what follows we present policy recommendations to promote innovation in ASEAN economies.

\section{Conclusions}

This paper verifies the existence of a cumulative process between internal capability and external sources. Internal capability directly enhances product as well as process innovation, while external sources promote product innovation indirectly via an enhancement of internal capability. In this sense, internal capability is the core of 
innovation, but it is not necessarily promoted without supplementary external sources. Regarding transmission channels, this paper identifies some important factors, such as the dispatch and acceptance of resident/guest engineers from an $\mathrm{MNC} / \mathrm{JV}$, cooperation with an $\mathrm{MNC} / \mathrm{JV}$ on the installation or maintenance of machines, and collaboration with an $\mathrm{MNC} / \mathrm{JV}$ on QC.

Table 2 Estimation result

\begin{tabular}{|c|c|c|c|c|c|c|c|}
\hline Innovation & Case 1 & Case 2 & Case 3 & Case 4 & Case 5 & Case 6 & Case 7 \\
\hline $\begin{array}{l}\text { Internal } \\
\text { capability } \\
\text { index }\end{array}$ & $2.315^{* * *}$ & $2.214 * * *$ & $2.121 * * *$ & $2.198 * * *$ & $2.263 * * *$ & $2.167 * * *$ & $\begin{array}{c}2.163 * * \\
*\end{array}$ \\
\hline \multicolumn{8}{|c|}{ Internal capability index } \\
\hline $\begin{array}{l}\text { External source } \\
\text { Observations }\end{array}$ & $\begin{array}{c}0.087 * * * \\
662\end{array}$ & $\begin{array}{c}0.109^{* * * *} \\
662\end{array}$ & $\begin{array}{c}0.084 * * * \\
662\end{array}$ & $\begin{array}{c}0.067 * * \\
662\end{array}$ & $\begin{array}{c}0.025 \\
662 \\
\end{array}$ & $\begin{array}{c}0.056^{*} \\
662\end{array}$ & $\begin{array}{c}0.050^{* *} \\
662\end{array}$ \\
\hline $\begin{array}{l}\text { Chi-squared } \\
\text { Prob }>\text { Chi2 }\end{array}$ & $\begin{array}{c}177.3 \\
0 \\
\end{array}$ & $\begin{array}{c}176.78 \\
0 \\
\end{array}$ & $\begin{array}{c}173.74 \\
0 \\
\end{array}$ & $\begin{array}{c}174.88 \\
0 \\
\end{array}$ & $\begin{array}{c}175.54 \\
0 \\
\end{array}$ & $\begin{array}{c}173.91 \\
0 \\
\end{array}$ & $\begin{array}{c}173.04 \\
0 \\
\end{array}$ \\
\hline $\begin{array}{l}\text { Chi-squared } \\
\text { (overidentifyin } \\
\text { g restrictions) } \\
\text { Prob }>\text { Chi2 }\end{array}$ & 0.5466 & 0.5398 & 0.5501 & 0.5553 & 0.5508 & 0.5517 & 0.5815 \\
\hline Innovation & Case 8 & Case 9 & Case 10 & Case 11 & Case 12 & Case 13 & \\
\hline $\begin{array}{l}\text { Internal } \\
\text { capability } \\
\text { index }\end{array}$ & $2.229 * * *$ & $2.522 * * *$ & $2.386^{* * *}$ & $2.258 * * *$ & $2.335 * * *$ & $2.248 * * *$ & \\
\hline \multicolumn{8}{|c|}{ Internal capability index } \\
\hline $\begin{array}{l}\text { External source } \\
\text { Observations }\end{array}$ & $\begin{array}{c}0.057 * * \\
662\end{array}$ & $\begin{array}{c}0.100^{* * *} \\
662\end{array}$ & $\begin{array}{c}0.107 * * * \\
662\end{array}$ & $\begin{array}{c}0.069^{* * *} \\
662\end{array}$ & $\begin{array}{c}0.079 * * * \\
662\end{array}$ & $\begin{array}{c}0.063 * * * \\
662\end{array}$ & \\
\hline $\begin{array}{l}\text { Chi-squared } \\
\text { Prob }>\text { Chi } 2 \\
\end{array}$ & $\begin{array}{c}174.35 \\
0 \\
\end{array}$ & $\begin{array}{c}184.43 \\
0 \\
\end{array}$ & $\begin{array}{c}179.08 \\
0 \\
\end{array}$ & $\begin{array}{c}175.35 \\
0\end{array}$ & $\begin{array}{c}177.78 \\
0 \\
\end{array}$ & $\begin{array}{c}175.62 \\
0 \\
\end{array}$ & \\
\hline $\begin{array}{l}\text { Chi-squared } \\
\text { (overidentifyin } \\
\text { g restrictions) } \\
\text { Prob }>\text { Chi } 2\end{array}$ & 2.076 & $\begin{array}{r}2.439 \\
0.4864\end{array}$ & 0.4933 & $\begin{array}{r}2.116 \\
0.5486\end{array}$ & $\begin{array}{r}2.134 \\
0.5451\end{array}$ & $\begin{array}{r}2.115 \\
0.5488\end{array}$ & \\
\hline $\begin{array}{l}\text { Note 1: Standard } \\
\text { Note 2: Case 1: Fin } \\
\text { customer (10 } \\
\text { country, Cas } \\
\text { 10: MNC/JV } \\
\text { organization }\end{array}$ & $\begin{array}{l}\text { rs in bracke } \\
\text { consumer, } \\
\text { o local cap } \\
\text { 3: MNC/JV } \\
\text { upplier loca }\end{array}$ & $\begin{array}{l}\text { * Significa } \\
\text { se 2: Comp } \\
\text { 1), Case 6: I } \\
\text { pplier locat } \\
\text { in a foreig }\end{array}$ & $\begin{array}{l}\text { at } 10 \%, * * \mathrm{~s} \\
\text { or, Case } 3 \text { : } \\
\text { al supplier }\end{array}$ & $\begin{array}{l}\text { nificant at } 5 \\
\text { yer or tradi } \\
0 \% \text { local ca } \\
\text { se } 9: \text { MNC/ } \\
1: \text { Public or }\end{array}$ & $\begin{array}{l}\text { significar } \\
\text { mpany, Cas } \\
\text {, Case 7: M } \\
\text { istomer loca } \\
\text { zation, Case }\end{array}$ & $\begin{array}{l}1 \% \text {. } \\
\text { Consultant, } \\
\text { JV customer } \\
\text { in a foreign } \\
\text { Local busin }\end{array}$ & $\begin{array}{l}\text { 5: Local } \\
\text { ntry, Case }\end{array}$ \\
\hline
\end{tabular}

\section{References}

Lawson B. \& D. Samson. (2001) Developing innovation capability in organizations: a dynamic capabilities approach, Inter. Jour. of Innovation Management, 5(3), 377-400.

Mariano N. \& Q. Pilar. (2005) Absorptive capacity, technological opportunity, knowledge spillovers, and innovative effort, Technovation, 25 (10), 1141-1157.

Zahra H. \& G. George. (1991) Absorptive Capacity: A Review, Reconceptualization, and Extension, Academy of Management Review, 27(2), 185-203. 
IJAHP Article: Mu, Saaty/A Style Guide for Paper Proposals To Be Submitted to the International Symposium of the Analytic Hierarchy Process 2014, Washington D.C., U.S.A.

Barney, J. (1991) Firm resources and sustained competitive advantage, Jour. of Management, 17, 99-120. 